immune systems and particularly of IgA concentrations, which normally rise with age, might also be expected to be delayed. Before treatment, however, four of the five children had IgA concentrations that lay within the normal range.

The early fall in IgA concentration after the start of treatment with thyroxine was unexpected. There is no reason to suppose that a return to normal metabolism will lead to a redistribution

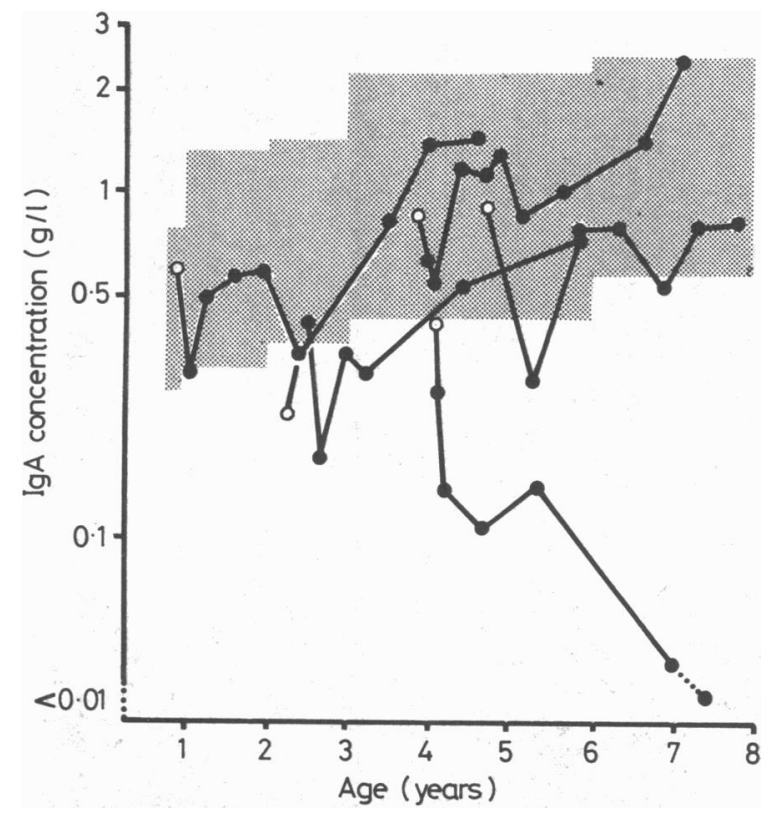

Immunoglobulin concentrations in five children before (O) and during ( $-O)$ treatment with thyroxine. The shaded area gives mean (2 SD) concentrations for healthy British children. ${ }^{2}$ of IgA within the body. The fall in IgA concentration is unlikely to have been due to a non-specific increase in catabolism as IgA has a shorter half life than IgG or IgM and should therefore be the least affected class of immunoglobulins. In selective IgA deficiency induced by phenytoin, ${ }^{3}$ and in many other immunoglobulin deficiencies, normal proportions of $\mathbf{B}$ cells bearing IgA have been found in the blood. Defective production of immunoglobulins has apparently been due to the failure of terminal maturation. In common variable hypogammaglobulinaemia Waldman et al showed that this failure may be due to the presence of suppressor $T$ lymphocytes in the circulation. ${ }^{4}$ This seems to be borne out by the recently described case of a patient with antibody deficiency induced by drugs who was shown to have abnormal suppressor $\mathrm{T}$ cell activity. ${ }^{5}$ The IgA deficiency seen here in children receiving hormone replacement treatment might have been due to stimulation of a $T$ cell suppressor system that, in the original hypothyroid state, was less than normally active.

I thank Dr T B Hales and the department of chemical pathology for immunoglobulin measurements and Miss L Blair for secretarial help.

\section{References \\ ${ }^{1}$ Delamere JP, Farr M, Grindulis KA. Sulphasalazine induced selective IgA deficiency in rheumatoid arthritis. Br Med $71983 ; 286: 1547-8$. \\ ${ }^{2}$ Hobbs JR. Simplified radial immunodiffusion. Association of clinical pathologists broadsheet 1970:No 68 (appendix). \\ ${ }^{3}$ Seager J, Jamison DL, Wilson J, Hayward AR, Soothill JF. IgA deficiency, epilepsy and phenytoin treatment. Lancet $1975 ;$ ii :632-5. \\ 4 Waldman TA, Durm M, Broder S, Blackman M, Blease RM, Strober W. Role of suppressor $T$ cells in pathogenesis of common variable hypo- gammaglobulinaemia. Lancet 1974;ii:609-13. \\ ${ }^{5}$ Dosch $\mathrm{H}-\mathrm{M}$, Jason J, Gelfand EW. Transient antibody deficiency and abnormal T suppressor cells induced by phenytoin. $N$ Englf $M e d 1982$; 306:406-9.}

(Accepted 1 March 1984)

\title{
Detection of hepatitis B virus DNA in mononuclear blood cells
}

\author{
P PONTISSO, M C POON, P TIOLLAIS, C BRECHOT
}

\begin{abstract}
The Southern transfer hybridisation technique was used to test mononuclear blood cells for hepatitis B virus DNA. Viral DNA sequences were detected in mononuclear cells of 10 out of 16 patients with hepatitis $B$ virus infection and in none of 21 normal controls. Blood contamination was excluded by the absence of hepatitis $B$ virus DNA in the corresponding serum samples in all cases.
\end{abstract}

\footnotetext{
Unité de Recombinaison et Expression Genetique (INSERM U 163, CNRS LA 271), Institut Pasteur, 75724 Paris Cedex 15, France P PONTISSO, MD

P TIOLLAIS, MD

C BRECHOT, MD
}

University of Calgary and Foothills Hospital, Calgary, Alberta, Canada T2N4N1

M C POON, MD

Correspondence to: Dr C Brechot.
Free monomeric hepatitis $B$ virus DNA was found in three patients positive for hepatitis Be antigen (HBeAg) and one positive for anti-HBe, and integrated hepatitis $B$ virus DNA was present in four patients positive for anti-HBe. In two other patients the small size of the samples did not allow a distinction between free and integrated viral DNA. The state of the virus in the mononuclear cells seemed to correlate with the $\mathrm{HBeAg}$ or anti-HBe state, as has been noted in the liver.

These results indicate that hepatitis $B$ virus may infect mononuclear blood cells, thereby expanding the tissue specificity of this agent beyond the liver, as has been reported for pancreatic, kidney, and skin tissue. They also suggest that hepatitis $B$ virus infection of mononuclear cells might be related to immunological abnormalities observed in carriers of the virus.

\section{Introduction}

Immunological abnormalities are often present in patients infected with hepatitis $B$ virus and may be responsible for 
hepatocellular injury and chronic viral persistence. ${ }^{1}$ Functional defects in proliferative $T$ cell response and suppressor $T$ cell function may be factors in both the inadequate immune response to hepatitis B surface antigen ( $\mathrm{HBsAg}$ ) and the putative hepatocytotoxic cellular immune response characteristic of chronic active hepatitis $\mathrm{B}^{2}$ In addition, functional and morphological alterations of lymphocytes that occur during other viral infections-such as with Epstein-Barr virus and cytomegalovirus -are found in patients with acute viral hepatitis B. $^{3}$

Different mechanisms may be responsible for the immunological abnormalities in hepatitis B virus infection, and both extrinsic and intrinsic factors have been identified. ${ }^{4}$ While hepatic bioregulatory molecules may be partially responsible for the extrinsic effect, ${ }^{5}$ the nature of the intrinsic effect is unknown. A direct effect of the hepatitis B virus on lymphocytes has been suggested, but intralymphocytic hepatitis B virus antigens have not been reported. With the advent of specific hepatitis $B$ virus DNA probes and sensitive DNA-DNA hybridisation assays we can now analyse the hepatitis $B$ virus genome independently of viral antigen expression.

We have used the Southern transfer hybridisation technique and report the detection of hepatitis $B$ virus DNA in mononuclear blood cells of patients with hepatitis $B$ virus infection.

\section{Patients and methods}

We studied 36 patients. Of these, 14 were $\mathrm{HBsAg}$ positive, of whom six were also $\mathrm{HBeAg}$ positive and eight anti-HBe positive; and two were $\mathrm{HBsAg}$ negative and anti-HBc and anti-HBs positive. One patient with haemophilia $A$ and acquired immune deficiency syndrome (AIDS) ${ }^{6}$ and two homosexual men with AIDS-like syndrome and disseminated histoplasmosis were among this group (see table). Histological examination of hepatic needle biopsy specimens was performed using the histological criteria of the international committee. ${ }^{7}$ The diagnosis was chronic persistent hepatitis in two patients, chronic active hepatitis in seven patients (one with liver cirrhosis), and resolving acute viral hepatitis in one; six patients had a normal liver. The control group comprised 21 healthy subjects, three of whom were anti-HBc and anti-HBs positive.

\section{SEROLOGICAL MARKERS AND ISOLATION OF MONONUCLEAR CELLS}

$\mathrm{HBsAg}$, anti-HBs, $\mathrm{HBeAg}$, anti-HBe, and anti-HBc were assayed by commercial solid phase radioimmunoassay (Abbott Laboratories, Chicago).

Mononuclear cells were isolated from $30 \mathrm{ml}$ blood anticoagulated with $10 \mathrm{mM}$ edetic acid using Ficoll-Hypaque density gradient centrifugation, according to standard procedures. ${ }^{8}$ Approximately $10^{7}$ to $10^{8}$ mononuclear cells were isolated in each preparation and corresponded to 100-150 $\mu \mathrm{g}$ cellular DNA. Viability of the cells, assessed by the trypan blue reagent, was $99 \%$. Total amount of cellular DNA was equilibrated to $20-30 \mu \mathrm{g}$ in each preparation before hybridisation experiments.

\section{HYBRIDISATION TECHNIQUES}

Serum hepatitis B virus DNA was assayed with a "spot" test technique using $50 \mu 1$ serum. ${ }^{\circ}$ Hepatitis B virus DNA in peripheral blood cells was detected by the Southern transfer hybridisation procedure. ${ }^{10}$ The viral DNA probe was obtained by insertion of the complete viral genome $e^{11}$ into the $\lambda$ bacteriophage. After cleavage with Eco RI restriction endonuclease the cloning vector was then removed by sucrose gradient centrifugation. Sequences of viral DNA were radiolabelled with phosphorus-32 by nick translation, the specific activity of the labelled DNA being $3 \times 10^{8} \mathrm{cpm} / \mu \mathrm{g}$. Cellular DNA was digested with Hind III and Eco RI (BioLabs, USA) before electrophoresis. ${ }^{\circ}$

The specificity of the results was supported by the absence of hepatitis B virus DNA sequences in all 21 controls studied. In order to exclude bacterial contamination we also dehybridised each nitrocellulose filter (previously hybridised with ${ }^{32} \mathrm{P}$-hepatitis B virus) with $0.005 \% \mathrm{Na}_{4} \mathrm{P}_{2} \mathrm{O}_{7}, 0.002 \%$ Ficoll, $0.002 \%$ povidone, $0.0002 \%$ bovine serum albumin, $0.2 \mathrm{M}$ edetic acid, and $0.5 \mathrm{mM}$ trometamol (TRIS) for three hours at $65^{\circ} \mathrm{C}^{12}$ and then rehybridised the sheets with radiolabelled $\lambda$ bacteriophage as probe (see fig 1). Only bands corresponding to $\lambda$ molecular weight marker were observed, while the mononuclear cell derived bands (previously detected with hepatitis $B$ virus probe) were absent (fig 1). The results were further confirmed by the use of a highly purified hepatitis B virus DNA probe prepared from a plasmid vector.

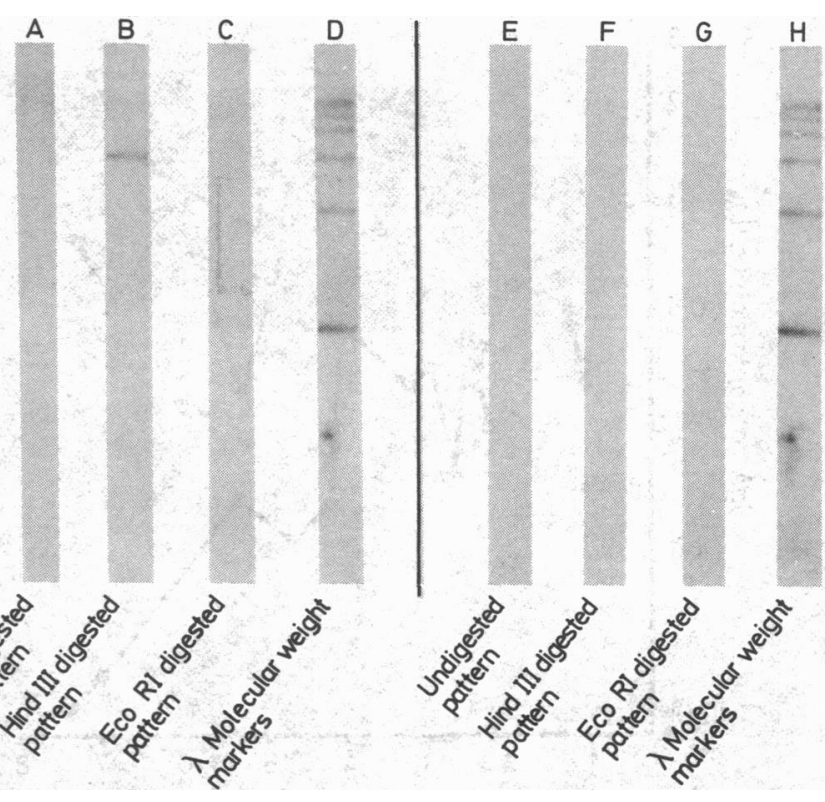

FIG 1-Autoradiograph of results of hepatitis B virus DNA blot hybridisation: example of specificity controls. In lanes A-C mononuclear cell DNA of patient was hybridised with hepatitis B virus DNA cloned into $\lambda$ bacteriophage and purified by sucrose gradient centrifugation. In lane $D \lambda(\operatorname{dv} 21$ DNA) oligomers were used as molecular weight markers. These were visible after five days because a small amount of $\lambda$ arms remained in viral DNA probe preparation and was then also labelled with $32 \mathrm{p}$. In lanes E-H same nitrocellulose filter was dehybridised and rehybridised with probe consisting of $\lambda$ phage DNA. Only $\lambda$ oligomers visible in autoradiograph (lane $H$ corresponds to autoradiography after 12 hours). Patterns show specificity of hybridisation observed with the hepatitis B virus DNA probe in lanes A-C. Same results were obtained with highly purified hepatitis B virus DNA probe derived from plasmid vector.

\section{Results}

Sequences of hepatitis B virus DNA were detected in the mononuclear cells of 10 out of 16 patients with hepatitis $B$ virus infection (table). The specificity of the results was supported by the absence of viral DNA sequences in the 21 control samples and the exclusion of bacterial contamination.

Several different autoradiographic patterns were observed (fig 2) after endonuclease digestion of cellular DNA with Hind III (which generally does not cut hepatitis B virus DNA) and Eco RI (which usually cuts the viral genome once). In the first pattern (fig 2; lanes A-C) Hind III digestion of cellular DNA resulted in one band at the 11 kilobase $(\mathrm{kb})$ position. This band was not observed in the uncut DNA pattern, where the hybridisation occurred only at the top of the gel, corresponding to very high molecular weight DNA. After Eco RI digestion a unique band at the fully cloned viral DNA position $(3.2 \mathrm{~kb})$ was observed. In the second pattern (fig 2 ; lanes D-F) a unique band was observed at the $3.2 \mathrm{~kb}$ position after both Hind III and Eco RI digestion. This band was not present in the uncut DNA pattern, where the hybridisation was detected at the top of the gel. These two patterns were observed in four patients seropositive for anti-HBe and seronegative for hepatitis $B$ virus DNA (table). In the third pattern (fig 2; lanes G-I) a discrete band at the $3.2 \mathrm{~kb}$ position, without any smear, was seen in the uncut DNA and after Hind III and Eco RI digestion. This was found in four patients (three seropositive for $\mathrm{HBeAg}$ and one seropositive for anti-HBe) without detectable serum hepatitis B virus DNA (table).

The fourth pattern reflected a weak hybridisation, with a short smear between the 3.2 and $2.0 \mathrm{~kb}$ positions and discrete bands superimposed in the uncut DNA and after Hind III and Eco RI 
Histological, serological, and hybridisation results in 16 patients with hepatitis $B$ virus infection

\begin{tabular}{|c|c|c|c|c|c|c|c|c|c|}
\hline \multirow{3}{*}{ Case No } & \multirow{3}{*}{ Histological findings } & \multicolumn{5}{|c|}{ Serological markers of hepatitis B virus } & \multicolumn{3}{|c|}{ Hepatitis B virus DNA } \\
\hline & & \multirow{2}{*}{ HBsAg } & \multirow{2}{*}{$\mathrm{HBeAg}$} & \multirow{2}{*}{ Anti-HBc } & \multirow{2}{*}{ Anti-HBe } & \multirow{2}{*}{ Anti-HBs } & \multicolumn{2}{|c|}{ Mononuclear cells } & \multirow{2}{*}{ Serum } \\
\hline & & & & & & & Free & Integrated & \\
\hline 1 & Normal liver & + & - & + & + & - & - & + & - \\
\hline 2 & Normal liver & + & - & + & + & - & - & + & - \\
\hline 3 & Normal liver & + & - & + & + & - & - & + & - \\
\hline 4 & Normal liver & + & - & + & + & - & - & - & - \\
\hline $5^{*}$ & Normal liver & + & + & + & - & - & $\dagger$ & $\dagger$ & - \\
\hline $6 \ddagger$ & Normal liver & + & + & + & - & - & - & - & + \\
\hline $8^{*}$ & Chronic persistent hepatitis & - & NT & + & NT & + & - & - & - \\
\hline $9 ! !$ & Chronic active hepatitis & + & - & + & + & - & - & - & - \\
\hline 10 & Chronic active hepatitis & + & - & + & + & - & - & + & - \\
\hline 11 & Chronic active hepatitis/cirrhosis & + & - & + & + & - & - & - & - \\
\hline 12 & Chronic active hepatitis & + & - & + & + & - & + & - & - \\
\hline 13 & Chronic active hepatitis & $f$ & + & + & - & - & + & - & - \\
\hline 14 & Chronic active hepatitis & + & + & + & - & - & + & - & - \\
\hline 15 & Chronic active hepatitis & + & + & + & - & - & - & - & + \\
\hline 16 & Acute viral hepatitis & + & + & + & - & - & + & - & - \\
\hline
\end{tabular}

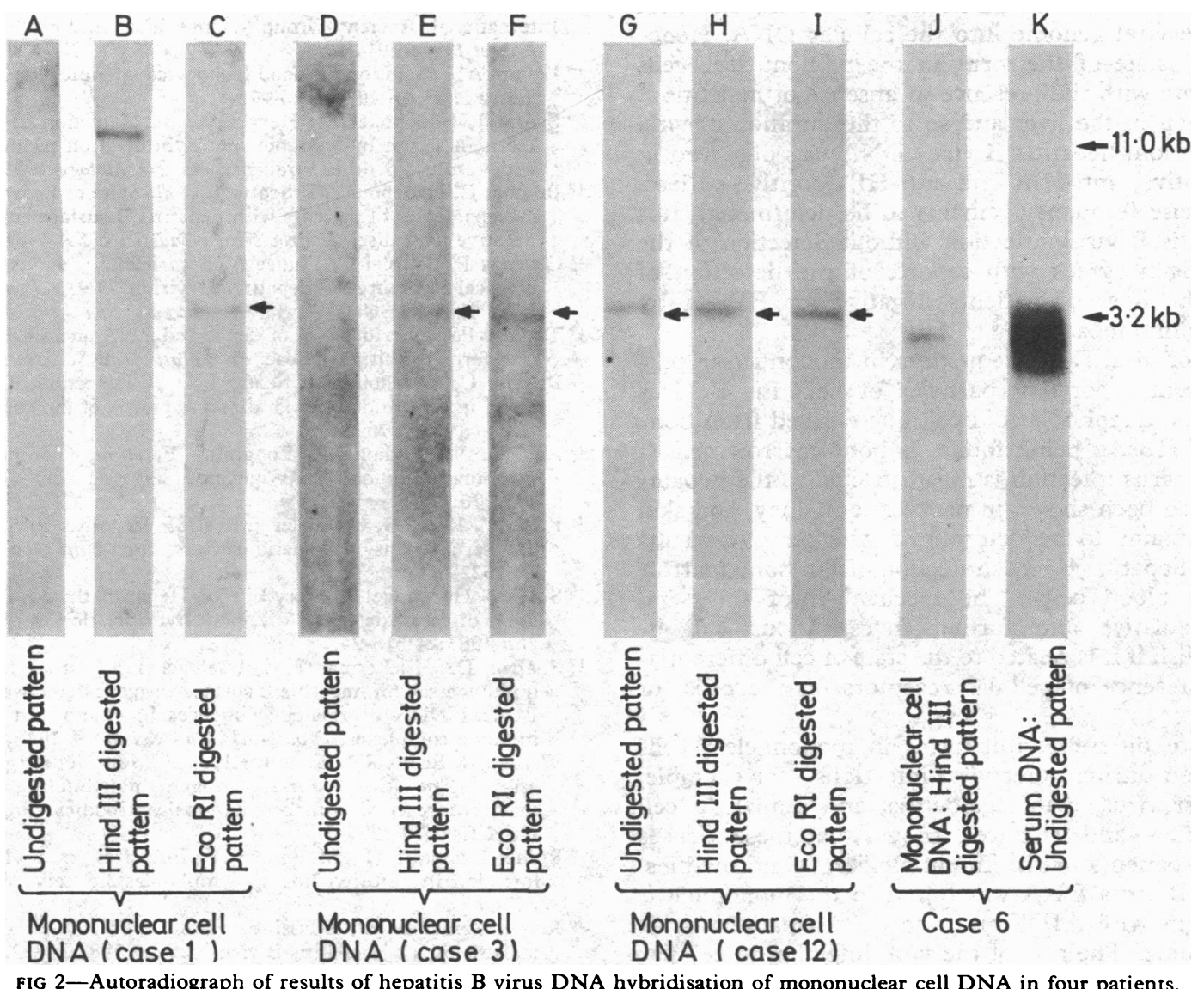

FIG 2-Autoradiograph of results of hepatitis B virus DNA hybridisation of mononuclear cell DNA in four patients.

digestion. There was no evidence of integration of viral genome into cellular DNA. These findings were observed in two $\mathrm{HBeAg}$ and serum viral DNA positive patients (table). The serum viral DNA was therefore analysed by the Southern procedure, and the autoradiographic patterns were the same as those observed for mononuclear cell DNA (fig 2; lanes J, K). Thus in these cases the hybridisation signal seemed to reflect blood contamination of the mononuclear cells. These preparations were therefore considered to be negative for hepatitis B virus DNA sequences.

Finally, two patients (one with haemophilia A and AIDS and one homosexual with AIDS-like syndrome) examined only with Eco RI (owing to limited sample size) showed a unique band at the $3.2 \mathrm{~kb}$ position. On the basis of this information alone it was not possible to establish the state of hepatitis B virus DNA in these samples (data not shown).

In none of the 21 normal controls were viral DNA sequences detected in mononuclear cells.

\section{Discussion}

This study shows that by using transfer hybridisation techniques hepatitis B virus DNA may be detected in mononuclear blood cells of some patients with hepatitis $B$ virus infection. Indeed blood contamination was excluded by the absence of free viral DNA in the corresponding serum samples.

Restriction enzyme digestion in patients found to have hepatitis B virus DNA showed different profiles. The first and second patterns were consistent with the presence of viral DNA sequences integrated into high molecular weight cellular DNA, as has been observed in the liver of chronic carriers of the virus. ${ }^{1013}$ Either clonal proliferation of infected cells or "non-random" integration of the viral DNA in cellular DNA may have been responsible for the discrete bands seen after Hind III digestion. The finding in the second pattern of a 
$3.2 \mathrm{~kb}$ band after both Hind III and Eco RI digestion may be explained by a Hind III restriction site in the viral DNA sequences. Indeed, recent reports from China indicate the existence of a discrete Hind III site in rare isolates of the adr subtype. ${ }^{14}$ The third pattern suggested the presence of free monomeric viral DNA sequences in the cells. This profile was observed in four cases in which serum hepatitis B virus DNA was not detectable by the spot test technique. Similar patterns, corresponding to unique bands at the $3.2 \mathrm{~kb}$ position, without detectable serum viral DNA, have been described in the liver of patients with hepatitis $B$ virus infection and are considered to reflect absence of overt viral multiplication..$^{15} 16$

When the results of hybridisation were compared with the $\mathrm{HBeAg}$ or anti-HBe state no evidence for cellular hepatitis B virus DNA sequences was obtained in the $\mathrm{HBeAg}$ and serum viral DNA positive patients. By contrast, free viral DNA sequences, without hepatitis $B$ virus multiplication, were detected in three out of four $\mathrm{HBeAg}$ positive patients and one anti-HBe positive patient, all of them being serologically negative for hepatitis B virus DNA. In four anti-HBe positive patients the restriction DNA patterns were consistent with integration of the viral genome into the cellular DNA. Hence the presence and state of the virus in the mononuclear cells seemed to correlate with the presence or absence of hepatitis B virus multiplication in the liver and so to the duration of viral infection. In addition, hepatitis B virus DNA was observed in one $\mathrm{HBsAg}$ negative, anti-HBc and anti-HBs positive patient. Although its precise frequency remains to be determined, this finding of hepatitis $B$ virus infection without detection of the viral surface antigen agrees with reports of the detection of viral DNA in the liver of patients negative for HBsAg by commercial radioimmunoassays. ${ }^{101718}$

The presence of viral DNA sequences in mononuclear cells accords with recent reports of particles of hepatitis B virus being detected in a lymphoblastoid cell line derived from bone marrow $^{19}$ and of $\mathrm{HBsAg}$ being found in bone marrow cells. ${ }^{20}$ Thus hepatitis B virus infection is not restricted to the hepatocytes, as it has also been shown in pancreatic, kidney, and skin tissue. ${ }^{21-22 a}$ It remains to be determined whether our results reflect a primary hepatitis $B$ virus infection of the bone marrow or of peripheral blood cells. The mechanism of this viral infection is speculative and further investigations will be required to establish if it is related to the state of cell differentiation or to the presence of cellular receptors on the cells, or both. ${ }^{23}$

The presence of different viral forms in mononuclear cells has been described during other viral infections-for example, with Epstein-Barr virus, cytomegalovirus, and human $T$ cell leukaemia virus ${ }^{24-26}$ - and it is well known that these viruses may coexist in patients with immunological abnormalities. Indeed hepatitis B virus DNA was found in the mononuclear cells of our patient with AIDS and one of two patients with AIDS-like syndrome. The role of the viral infection in cellular immunodeficiency is still to be established. Our findings, however, support current hypotheses concerning the relation between infection with hepatitis $B$ virus and AIDS. ${ }^{27} 28$ Prospective studies will determine whether the presence of mononuclear cell hepatitis B virus DNA is related to any global or specific defect in mononuclear cell function and whether the state of the viral genome in peripheral mononuclear cells corresponds with that in the liver.

\section{ADDENDUM}

Since submission of this manuscript HBV DNA sequences were also detected in white blood cells from HBV carriers by Lie-Injo et al (DNA 1983;2:301-7).

We thank Dr F V Chisari for his suggestions and help in preparing the manuscript. We are also grateful to Dr C Gazengel, Dr M F Torchet, Mrs A M Couroucé, Dr Mourau, Dr Boulard, Dr F M
Griffin, Dr N J Cannon, Dr F Degos, and Dr B Nalpas for providing blood samples from their patients.

\section{References}

1 Dienstag L, Bham AK, Klingenstein RJ, et al. Immunopathogenesis of liver disease associated with hepatitis B. In: Szmuness W, Alter HJ, Maynard JE, eds. Viral hepatitis. Philadelphia: The Franklin Institute Press, 1982:221-6.

${ }^{2}$ Eddleston ALWF, Mondelli M, Mieli-Vergani G, et al. Lymphocyte cytotoxicity to autologous hepatocytes in chronic hepatitis $\mathbf{B}$ virus infection. Hepatology $1982 ; 2: 122-7 \mathrm{~s}$.

${ }^{3}$ Laiwak AACY. Lymphocyte transformation by Australia antigen. Lancet 1971 ;ii:470-1.

4 Chisari FV, Routenberg JA, Edgington TS. Mechanisms responsible for defective human $\mathrm{T}$-lymphocyte sheep rosette function associated with hepatitis B virus infection. $\mathcal{F}$ Clin Invest 1976;57:1127-238.

${ }^{5}$ Chisari FV. Regulation of lymphocyte function and viral transformation by hepatic bioregulatory molecules. Hepatology 1982;2:97-106s.

${ }^{6}$ Poon MC, Landay A, Prasthofes ES, Stagno S. Acquired immunodeficiency syndrome with Pneumocystis carinii pneumonia and Mycobacterium avium intracellular infection in a previously healthy patient with classic hemophilia. Clinical, immunologic and virologic findings. Ann Intern Med 1983;98:287-90.

' International Review Group. Acute and chronic hepatitis revisited. Lancet 1977;ii:914-9.

${ }^{8}$ Boyum A. Separation of blood leukocytes, granulocytes and lymphocytes. Tissue Antigens 1974;4:269-73.

${ }^{9}$ Scotto J, Hadchouel M, Hery C, et al. Detection of hepatitis B virus DNA in serum by a simple spot hybridization technique: comparison with results for other viral markers. Hepatology 1983;3:279-84.

10 Brechot C, Hadchouel M, Scotto J, et al. State of hepatitis B virus DNA in hepatocytes of patients with hepatitis $B$ surface antigen positive and negative liver disease. Proc Natl Acad Sci USA 1981;78:3906-10.

"Charnay P, Pourcel C, Louise A, et al. Cloning in Escherichia coli and physical structure of hepatitis B virion DNA. Proc Natl Acad Sci $U S A$ 1980;76:3683-7.

12 Thomas PS. Hybridization of denatured RNA and small DNA fragments transferred to nitrocellulose. Proc Natl Acad Sci USA 1980;77:5201-5.

${ }^{13}$ Brechot C, Hadchouel M, Scotto J, et al. Detection of hepatitis B virus DNA in liver and serum: a direct appraisal of the chronic carrier state. Lancet 1981 ;ii:765-8.

14 Xianggu W, Yizhong $\mathrm{Z}$, Zongming $\mathrm{F}$, et al. Cloning and restriction mapping of human HBV genome serotype adr. Sci Sin (series B) $1983 ; 26: 162-7$

${ }^{15} \mathrm{Kam}$ W, Rall LB, Smuckler EA, et al. Hepatitis B viral DNA in liver and serum of asymptomatic carriers. Proc Natl Acad Sci USA 1982; 79:7522-6.

${ }^{16}$ Scotto J, Hadchouel M, Hery F, et al. Hepatitis B virus DNA in children's liver disease: detection by blot hybridization in liver and serum. Gut 1983;24:618-24.

17 Shafritz DA, Lieberman HM, Isselbacher KJ, et al. Monoclonal radioimmunoassay for hepatitis B surface antigen: demonstration of hepatitis $B$ virus DNA or related sequences in serum and viral epitopes in immune complexes. Proc Natl Acad Sci USA 1982;79:5675-9.

18 Wands JR, Bruns RR, Carlson RI, et al. Monoclonal IgM radioimmunoassay for hepatitis $B$ surface antigen: high binding activity in serum that is unreactive with conventional antibodies. Proc Natl Acad Sci $U S A$ 1982;79:1277-81.

${ }^{19}$ Romet-Lemonne JP, McLane MF, Elfassi E, et al. Hepatitis B virus infection in cultured human lymphoblastoid cells. Science 1983;221: 667-9.

${ }^{20}$ Romet-Lemonne JP, Elfassi E, Haseltine W, et al. Infection of bone marrow cells by hepatitis B virus. Lancet 1983;ii:732.

${ }^{21}$ Halpern MS, England JM, Deery DT, et al. Viral nucleic acid synthesis and antigen accumulation in pancreas and kidney of Pekin ducks infected with duck hepatitis B virus. Proc Natl Acad Sci USA 1983; 80:4865-9.

22 Siqquidi A. Hepatitis B virus DNA in Kaposi sarcoma. Proc Natl Acad Sci USA $1983 ; 80: 4861-4$.

22a Dejean A, et al. $\mathcal{F}$ Gen Virol (in press).

${ }^{23}$ Thung $S$, Gerber MA. Hepatitis $B$ virus and polyalbumin binding sites. Gastroenterology 1983;85:466-8.

${ }^{24}$ Rinaldo CR, Richter BS, Black PH, et al. Replication of herpes simplex virus and cytomegalovirus in human leucocytes. F Immunol 1978;120: 130-6.

${ }^{25}$ Reinerz EL, O'Brien C, Rosenthal P, et al. The cellular basis for viralinduced immunodeficiency: analysis by monoclonal antibodies. $\mathcal{f}$ Immunol 1980;125:1269-74.

${ }^{26}$ Gelmann EP, Popovic M, Blayney D, et al. Proviral DNA of a retrovirus, human T-cell leukemia virus, in two patients with AIDS. Science 1983;220:862-5.

27 McDonald M, Hamilton JD, Dirack DT. Hepatitis B surface antigen could harbour the infective agent of AIDS. Lancet 1983;ii:882-4.

${ }^{28}$ Ravenholt RT. Role of hepatitis $B$ virus in acquired immunodeficiency syndrome. Lancet 1983;ii:885-6.

(Accepted 14 February 1984) 